\title{
HUBUNGAN KONSEP DIRI, KOMITMEN, DAN MOTIVASI BERPRESTASI DENGAN PRESTASI RENANG GAYA BEBAS
}

\author{
Boyke Mulyana \\ FPOK Universitas Pendidikan Indonesia \\ email: boyke.mulyana@yahoo.com
}

\begin{abstract}
Abstrak: Penelitian ini bertujuan untuk mengetahui hubungan antara konsep diri, komitmen, dan motivasi berprestasi dengan prestasi renang $100 \mathrm{~m}$ gaya bebas. Metode penelitian yang digunakan survai. Sampel penelitiannya atlet renang Jawa Barat berjumlah 35 orang dan diambil melalui teknik random. Hasil penelitian menunjukkan bahwa ada hubungan yang signifikan antara: (1) konsep diri dan prestasi renang 100m gaya bebas; (2) komitmen dan prestasi renang $100 \mathrm{~m}$ gaya bebas; (3) motivasi berprestasi dan prestasi renang $100 \mathrm{~m}$ gaya bebas; dan (4) konsep diri, komitmen, dan motivasi berprestasi secara bersama-sama dengan prestasi renang $100 \mathrm{~m}$ gaya bebas.
\end{abstract}

Kata Kunci: konsep diri, komitmen, motivasi berprestasi, dan prestasi renang gaya bebas

\section{THE RELATIONSHIPS BETWEEN SELF-CONCEPT, COMMITMENT, AND ACHIEVEMENT MOTIVATION WITH FREESTYLE SWIMMING ACHIEVEMENT}

\begin{abstract}
The Study is aimed at finding out the relationship between self-concept, commitment, and achievement motivation with freestyle swimming achievement. The method used in this research is suevai method. The samples in this research is swimming atheletes consisted with 35 samples selected randomly. The result of the study indicated positive relationship between: (1) self-concept with freestyle swimming achievement; (2) commitment with freestyle swimming achievement; and (3) achievement motivation with freestyle swimming achievement. There is also a positive and significant correlation between slefconcept, commitment, and achievement motivation together with freestyle swimming achievement.
\end{abstract}

Keywords: self concept, commitment, achievement motivation, freestyle swimming achievement

\section{PENDAHULUAN}

Olahraga renang terdiri dari empat gaya yang dilombakan, yaitu: gaya kupukupu, gaya punggung, gaya dada, dan gaya bebas. Prestasi olahraga renang tidak mudah diraih, karena banyak faktor yang menentukan prestasi perenang, seperti faktor anatomi (panjang lengan, tinggi badan, panjang tungkai); faktor fisiologi (kemampuan menghirup oksigen, kelincahan, keseimbangan, koordinasi, kekuatan, power, fleksibilitas); faktor biomekanika (kecepat- an gerak, dan frekuensi kayuhan); faktor psikologi (kepribadian, atribusi, motivasi berprestasi, agresi, arausal, kecemasan, stress, aktivasi, kepemimpinan, komunikasi, komitmen, imagery, konsentrasi, konsep diri, dan rasa percaya diri). Dari beberapa faktor di atas, khususnya faktor psikologis belum banyak diteliti, maka dalam penelitian ini akan mengkaji hubungan antara konsep diri, komitmen, dan motivasi berprestasi dengan prestasi atlet 
cabang olahraga renang, khususnya pada renang $100 \mathrm{~m}$ gaya bebas.

Konsep diri sebagai faktor yang menentukan dalam komunikasi interpersonal, karena setiap orang bertingkah laku sesuai dengan konsep diri yang dimiliki (Husdarta, 2010:93). Artinya, dalam setiap tingkah laku yang dilakukan perenang dalam proses mencapai prestasi akan sesuai dengan konsep diri yang dimiliki. Perenang yang memiliki konsep diri akan yakin pada kemampuan dirinya dan merasa setara dengan lawan yang dihadapi, sehingga perenang mampu meminimalisir kesalahan yang terjadi.

Dimensi lain yang berhubungan dengan prestasi renang adalah komitmen, yang merupakan dasar kekuatan perenang dalam melaksanakan tugas dan tanggung jawab. Komitmen menjadikan perenang memiliki motivasi yang tinggi dan mendorong untuk menyelesaikan tugas dalam mewujudkan prestasi yang ingin dicapai. Komitmen yang kuat mampu mendorong perenang untuk berbuat tanpa pamrih, konsisten, konsekuen, ikhlas, dan cinta akan profesinya. Perenang yang memiliki komitmen tinggi dapat berlatih secara ulet, tekun, dan mencari jalan terbaik untuk menyelesaikan tugasnya secara efektif dan efisien.

Selanjutnya, motivasi berprestasi merupakan dorongan yang ada dalam diri seseorang untuk berusaha meningkatkan kemampuannya dengan menggunakan standar keunggulan. Motivasi berprestasi perenang akan mempengaruhi kinerjanya terhadap prestasi renang $100 \mathrm{~m}$ gaya bebas dalam setiap perlombaan. Hasil penelitian Mc Clelland (Cox, 2002) menunjukkan bahwa: "Motivasi berprestasi yang tinggi selalu diikuti dengan penampilan yang superior." Hal itu menunjukkan bahwa pentingnya motivasi berprestasi untuk mencapai prestasi dalam olahraga. Selanjutnya, untuk meningkatkan prestasi renang $100 \mathrm{~m}$ gaya bebas, konsep diri, komitmen, dan motivasi berprestasi penting dimiliki oleh atlet renang, tetapi nampaknya secara parsial maupun integral masih belum diketahui secara pasti. Dari uraian di atas untuk meningkatkan prestasi renang $100 \mathrm{~m}$ gaya bebas, maka kuat tidaknya pengaruh ketiga faktor yaitu: konsep diri, komitmen, dan motivasi berprestasi baik secara parsial maupun integral masih belum diketahui secara pasti. Oleh karena itu, peneliti tertarik untuk mengkaji hubungan antarvariabel tersebut, guna mendapatkan fakta empirik melalui penelitian.

Konsep diri menurut Hurlock (Wangmuba, 2009:1) adalah gambaran yang dimiliki individu tentang dirinya; meliputi karateristik fisik, sosial, psikologis, emosional, aspirasi, dan prestasi. Konsep diri adalah persepsi seseorang terhadap dunia ini mempengaruhi cara orang tersebut bertindak. Jadi konsep diri merupakan persepsi seseorang terhadap dirinya secara menyeluruh, sehingga dapat mengarahkan interaksi perenang dengan lingkungan, dan secara timbal balik pengalaman perenang dengan lingkungan mempengaruhi pembentukan konsep diri.

Dalam membentuk konsep diri, seorang perenang tidak lepas dari diri fisik, diri moral, diri pribadi, diri sosial, dan kritik diri. Seseorang mempersiapkan diri berdasarkan dunia batinnya sendiri dan berdasarkan interaksinya dengan dunia luar, yaitu peran sosial, aktivitas, dan nilai-nilai yang dianut. Diri yang dipersepsi berdasarkan dunia batin seseorang disebut dimensi internal yang meliputi self identity, self behavioral, dan self judging. Diri yang dipersepsikan berdasarkan peran, aktivitas, dan nilai-nilai yang dianut orang disebut dimensi eksternal dari konsep diri yang 
meliputi physical self, moral ethical self, personal self, family self, dan social self.

Kesimpulannya konsep diri merupakan kesadaran batin yang permanen, konsekuen, konsisten, dan merupakan inti dari penampilan diri dan tingkah laku yang dicapai dengan berpedoman pada patokan prestasi terbaik yang pernah dicapai baik oleh dirinya maupun orang lain. Konsep diri di atas tergambar dalam kemampuan perenang sebagai makhluk pribadi maupun makhluk sosial yang dipengaruhi oleh dimensi internal dan eksternal, yang ditandai oleh (1) dimensi internal, dengan indikator diri identitas, diri pelaku, dan diri penilai; (2) dimensi eksternal, dengan indikator diri etik moral, diri pribadi, dan diri sosial.

Komitmen sebagai suatu kekuatan yang mengikat individu untuk melakukan aksi yang relevan dengan sasaran tertentu (Meyer dan Herscovitch, 2001:98). Menurut Jenny (2009:2) komitmen adalah sesuatu yang membuat individu rela membulatkan hati dan tekad demi mencapai suatu tujuan, sekalipun individu belum dapat mengetahui hasil akhir dari tujuan tersebut. Pendapat lain menyatakan bahwa komitmen adalah langkah (tindakan) yang diambil untuk menopang suatu pilihan tindakan tertentu, sehingga pilihan tindakan itu dapat dijalankan mantap dan sepenuh hati (Panggabean, 2012:1, http://diahkei.staff.ugm.ac.id/file/komitmen, diunduh 23 Mei 2012). Dengan demikian, individu yang memiliki komitmen dalam melakukan tugas dan kewajiban akan selalu termotivasi dan gigih dalam meraih target yang ingin dicapai.

Tumbuhnya komitmen akibat dari pengaruh lingkungan, khususnya lingkungan pekerjaan individu. Komitmen untuk mengenal diri dan beradaptasi dengan pekerjaannya dapat tumbuh di kalangan perenang jika perenang diterima dengan baik oleh pelatih maupun manajer. Perenang selalu belajar untuk membangun komitmen dirinya dengan berusaha mencintai tanggung jawabnya, rasa cinta akan sesuatu, dan kemauan serta semangat yang kuat dengan sasaran tertentu dalam menjalankan tugas. Eksistensi komitmen perenang dapat dilihat dari indikator, di antaranya: (1) kecintaan pada peran; (2) kepercayaan pada misi dan tujuan yang dibebankan; (3) keterikatan untuk menjaga nama baik; (4) tanggapan terhadap tantangan yang ada; dan (5) keikhlasan dalam menjalankan tugas.

Motivasi berprestasi adalah dorongan seseorang berkaitan dengan prestasi, yang memiliki ciri-ciri; menguasai, memanipulasi, mengatur lingkungan sosial maupun fisik, mengatasi rintangan, dan memelihara kualitas kerja yang tinggi, bersaing melalui usaha untuk melebihi perbuatan yang lampau serta mengungguli perbuatan orang lain. Adanya "achievement motivation" yang merupakan motivasi intrinsik adalah daya penggerak dalam diri seseorang untuk mencapai prestasi. Motivasi berprestasi merupakan motivasi yang mendorong individu untuk sukses, dan bertujuan untuk berhasil dalam kompetisi dengan beberapa ukuran keunggulan (standard of excelence). Ukuran keunggulan adalah patokan yang berhubungan dengan tugas, yaitu menilai berdasarkan pencapaian hasil dan patokan yang berhubungan dengan prestasi yang pernah dicapai sendiri pada masa lalu.

Motivasi berprestasi berhubungan dengan pola tindakan dan perasaan yang terkait dengan kerja keras dan perjuangan tidak kenal menyerah dalam berlatih untuk dapat mencapai prestasi yang tinggi. Karakter atlet yang memiliki motivasi berprestasi tinggi biasanya (1) mengerjakan tugas tepat waktu, berusaha menyelesaikan tugas yang direncanakan sendiri, pelatih, atau kelom- 
pok; dan (2) bertanggung jawab terhadap keberhasilan dalam berlatih. Atlet yang memiliki motivasi berprestasi sebagai kebutuhan berharap untuk sukses dan bersikap positif terhadap tujuan yang akan dicapai, serta tidak banyak memikirkan kegagalan.

Berdasarkan kajian teori, motivasi berprestasi atlet diidentifikasi melalui indikator: (1) mempunyai kemauan keras/suka bekerja keras dan tidak kenal menyerah dalam berlatih; (2) mempunyai harapan untuk sukses; (3) bertanggung jawab terhadap keberhasilan dalam berlatih dan selalu berorientasi kedepan dan diwujudkan dalam bentuk tingkah laku.

Prestasi adalah hasil yang dicapai dari apa yang dikerjakan atau yang sudah diusahakan. Jadi, prestasi adalah hasil yang diperoleh dari usaha, kerja, kemampuan yang dilakukan seseorang atau suatu tim, seperti: menjuarai suatu kompetisi, memecahkan rekor, memenangkan pertandingan perebutan gelar atau pertandingan bergengsi lainnya.

Renang gaya bebas adalah salah satu nomor cabang olahraga renang yang dilatih pada perenang. Menurut FINA (Federation Internationale de Natation Amateur) (2010: 126) gaya bebas ditetapkan bahwa perenang dapat berenang suatu gaya apa saja, kecuali dalam nomor gaya ganti perorangan dan gaya ganti estafet. Gaya bebas adalah gaya yang berbeda dari gaya punggung, gaya dada, dan gaya kupu-kupu. Jadi, prestasi renang gaya bebas adalah hasil dari usaha yang dilakukan seseorang dalam melakukan renang gaya apa saja dan berbeda dari gaya punggung, gaya dada, dan gaya kupu-kupu. Jika dikaitkan dengan renang $100 \mathrm{~m}$ gaya bebas, maka prestasi renang adalah kecepatan perenang dalam menempuh jarak renang $100 \mathrm{~m}$ dengan gaya bebas.

Hubungan dari ketiga faktor tersebut dengan prestasi renang $100 \mathrm{~m}$ gaya bebas adalah sebagai berikut. Hubungan antara konsep diri dan prestasi renang $100 \mathrm{~m}$ gaya bebas. Konsep diri pada perenang dapat dilihat dari kemampuan sosial, intelektual, dan prestasinya. Hal ini berdampak pada kedudukan, peranan, dan penghargaan yang diperoleh perenang dari komunitasnya. Perenang yang memiliki tingkat intelektual yang baik akan memiliki banyak cara untuk mengatasi permasalahan pada saat latihan/ perlombaan. Dengan demikian, diduga terdapat hubungan antara konsep diri dan prestasi renang $100 \mathrm{~m}$ gaya bebas.

Hubungan antara komitmen dan prestasi renang $100 \mathrm{~m}$ gaya bebas. Komitmen merupakan suatu kekuatan perenang untuk mencapai sukses, dengan komitmen yang kuat maka perenang akan termotivasi untuk melaksanakan tugas dan kewajibannya dengan baik. Mencintai peran menjadikan perenang tetap setia pada tujuan sebagai perenang yang baik, patuh, ulet, cerdas, bijaksana, dan berprestasi. Tumbuhnya komitmen perenang yang didasari oleh kecintaan pada peran dan didukung kepercayaan diri akan berdampak pada prestasi yang dicapai. Dengan demikian, diduga terdapat hubungan antara komitmen dan prestasi renang $100 \mathrm{~m}$ gaya bebas.

Hubungan antara motivasi berprestasi dan prestasi renang $100 \mathrm{~m}$ gaya bebas. Motivasi berprestasi pada perenang berhubungan dengan pola tindakan dan perasaan yang berkaitan dengan kerja keras dan perjuangan tidak kenal menyerah dalam berlatih. Tujuannya untuk mencapai prestasi renang yang tinggi melalui persaingan dengan diri sendiri atau perenang lain. Karakteristik perenang yang memiliki motivasi berprestasi tinggi adalah memiliki kemauan keras/suka bekerja keras, harapan untuk suskses, bertanggung jawab, dan selalu berorientasi ke depan dan diwujudkan dalam bentuk tingkah laku. Dengan demikian, 
diduga terdapat hubungan antara motivasi berprestasi dan prestasi renang $100 \mathrm{~m}$ gaya bebas.

Hubungan antara konsep diri, komitmen, dan motivasi berprestasi secara bersama-sama terhadap prestasi renang $100 \mathrm{~m}$ gaya bebas. Konsep diri perenang yang disegani oleh seluruh perenang lainnya pada saat latihan/perlombaan menandakan perenang memiliki kemampuan sosial yang tinggi, kemampuan intelektual baik, dan prestasi baik pada cabang olahraga renang. Perenang yang memahami konsep diri lebih utuh umumnya dapat mengatasi permasalahan yang dihadapi. Hal ini berarti bahwa perenang yang memiliki konsep diri baik akan mempunyai hubungan yang positif dengan prestasi renang $100 \mathrm{~m}$ gaya bebas.

Komitmen yang timbul pada perenang akibat kecintaan pada peran, kepercayaan pada misi dan tujuan yang dibebankan, keterkaitan untuk menjaga nama baik peran, reaksi terhadap tantangan yang dihadapi, dan keikhlasan dalam menjalankan tugas. Artinya, bahwa perenang yang memiliki komitmen tinggi akan mempunyai hubungan yang positif dengan prestasi renang $100 \mathrm{~m}$ gaya bebas.

Motivasi berprestasi perenang ditampakkan melalui kerja keras yang tidak kenal menyerah dalam berlatih, bertanggung jawab terhadap keberhasilan latihan, percaya diri, dan berorientasi ke masa depan melalui dimensi keunggulan dalam bentuk prestasi renang yang terbaik bagi dirinya, dan lebih baik dari perenang lain. Hal ini berarti bahwa perenang yang memiliki motivasi berprestasi yang tinggi akan mempunyai hubungan yang positif dengan prestasi renang $100 \mathrm{~m}$ gaya bebas.

Perenang yang memiliki konsep diri yang baik, komitmen yang tinggi, dan motivasi berprestasi yang tinggi diduga pada diri perenang akan memiliki hubungan yang positif dengan prestasi renang 100m gaya bebas. Dengan demikian konsep diri, komitmen, dan motivasi berprestasi secara bersama-sama diduga memiliki hubungan positif dengan prestasi renang $100 \mathrm{~m}$ gaya bebas.

Untuk itu, permasalahan dalam penelitian ini adalah hubungan antara konsep diri, komitmen, dan motivasi berprestasi dengan prestasi renang $100 \mathrm{~m}$ gaya bebas. Masalah penelitian ini terkait dengan halhal sebagai berikut: hubungan antara konsep diri dan pestasi renang $100 \mathrm{~m}$ gaya bebas, hubungan antara komitmen dan prestasi renang $100 \mathrm{~m}$ gaya bebas, hubungan antara motivasi berprestasi dan prestasi renang $100 \mathrm{~m}$ gaya bebas, hubungan antara konsep diri, komitmen, dan motivasi berprestasi secara bersama-sama dengan prestasi renang $100 \mathrm{~m}$ gaya bebas.

\section{METODE}

Metode penelitian yang digunakan adalah survai dengan bentuk penelitian korelasional. Metode survei dipilih karena di dalam pengumpulan data tidak dibuat perlakuan atau pengkondisian terhadap variabel, tetapi mengungkap fakta berdasarkan gejala yang telah ada pada atlet. Metode survei dirancang untuk memperoleh informasi tentang status gejala pada saat penelitian dilakukan, tujuannya untuk melukiskan variabel atau kondisi apa yang terjadi pada suatu situasi (Creswel, 2010). Bentuk penelitian korelasional dipilih karena mengkaji dan mengungkapkan hubungan antara variabel bebas dengan variabel terikatnya.

Penelitian ini terdiri dari tiga variabel bebas yaitu: (1) konsep diri, (2) komitmen, dan (3) motivasi berprestasi, serta prestasi renang $100 \mathrm{~m}$ gaya bebas sebagai variabel terikat. Proses pengumpulan data penelitian ini menggunakan tiga instrumen yang 
terkait dengan variabel bebas yang diteliti yaitu, konsep diri, komitmen, motivasi berprestasi, dan untuk variabel terikat menggunakan tes prestasi renang $100 \mathrm{~m}$ gaya bebas. Prestasi renang diukur menggunakan Fronske Swimming Test (Bradford dan Wilson, 1993:66). Hasil yang dicatat adalah waktu yang ditempuh oleh perenang sejauh $100 \mathrm{~m}$, dengan menggunakan stopwatch (alat pencatat waktu). Penelitian ini tidak mengembangkan tes prestasi renang yang baru karena tes ini sudah baku dan layak digunakan sebagai alat ukur, karena memiliki tingkat validitas sebesar 0.67 dan reliabilitas sebesar 0.93. Untuk menjamin keakuratan data penelitian, teknik yang digunakan untuk pengambilan data dilakukan secara bertahap, artinya tidak semua instrumen penelitian diberikan kepada sampel dalam jangka waktu satu hari, namun dilakukan dua hari pengambilan data, dan dilaksanakan pada sore hari.

\section{HASIL DAN PEMBAHASAN \\ Hasil}

Data dalam penelitian ini terdiri dari data konsep diri, data komitmen, data motivasi berprestasi, dan data prestasi renang 100m gaya bebas.oleh karena data penelitian memiliki satuan yang berbeda, maka perlu distandarisasi menggunakan ( $T$-skor). Hasil penghitungan koefisien korelasi $X_{1}$ dengan $\mathrm{Y}\left(\mathrm{r}_{\mathrm{y}_{1}}\right)$ diperoleh $\mathrm{r}_{\mathrm{y}_{1}}=0,527$. Koefisien korelasi $r_{y_{1}}$ melalui uji-t, hasilnya seperti pada Tabel 1.

Hasil yang menunjukkan bahwa $\mathrm{t}_{\text {hitung }}=2,207>\mathrm{t}_{\text {tabel }} 1,70$, maka hipotesis yang berbunyi terdapat hubungan antara konsep diri dan prestasi renang $100 \mathrm{~m}$ gaya bebas, diterima. Artinya, terdapat hubungan yang signifikan antara konsep diri dan prestasi renang $100 \mathrm{~m}$ gaya bebas. Dari koefisien $\mathrm{r}_{\mathrm{y} 1}$ tersebut di atas diperoleh koe- fisien determinasi $\left(\mathrm{r}^{2}\right)=0,278$. Artinya, bahwa $27,8 \%$ variasi prestasi renang $100 \mathrm{~m}$ gaya bebas dapat dijelaskan oleh variasi konsep diri. Hasil penghitungan koefisien korelasi $\mathrm{X}_{2}$ dengan $\mathrm{Y}\left(\mathrm{r}_{\mathrm{y} 2}\right)$, diperoleh $\mathrm{r}_{\mathrm{y} 2}$ sebesar 0,584. Signifikansi koefisien korelasi $r_{y} 2$ melalui uji-t, hasilnya seperti pada Tabel 2.

\section{Tabel 1. Hasil Penghitungan Korelasi} $\mathrm{X}_{1}$ dengan $\mathrm{Y}$

\begin{tabular}{ll}
\hline Korelasi & $\mathrm{X}_{1}$ dengan $\mathrm{Y}$ \\
\hline $\mathrm{n}$ & 35 \\
$\mathrm{R}$ & 0.527 \\
$\mathrm{r}^{2}$ & 0,278 \\
$\mathrm{t}_{\text {hitung }}$ & 2,207 \\
$\mathrm{t}_{\text {tabel }}$ & \\
0,05 & 2,46 \\
0,01 & 1,70 \\
\hline
\end{tabular}

Tabel 2. Hasil Penghitungan Korelasi $X_{2}$ dengan $Y$

\begin{tabular}{ll}
\hline Korelasi & $\mathrm{X}_{1}$ dengan $\mathrm{Y}$ \\
\hline $\mathrm{n}$ & 35 \\
$\mathrm{R}$ & 0,584 \\
$\mathrm{r}^{2}$ & 0,341 \\
$\mathrm{t}_{\text {hitung }}$ & 1,736 \\
$\mathrm{t}_{\text {tabel }}$ & \\
0,05 & 2,46 \\
0,01 & 1,70 \\
\hline
\end{tabular}

Hasil yang menunjukkan bahwa $t_{\text {hitung }}=1,736>t_{\text {tabel }} 1,70$, maka hipotesis yang berbunyi terdapat hubungan antara komitmen dan prestasi renang $100 \mathrm{~m}$ gaya bebas, diterima. Artinya, terdapat hubungan yang signifikan antara komitmen dan prestasi renang $100 \mathrm{~m}$ gaya bebas. Berdasarkan koefisien $r_{\mathrm{y} 2}$ tersebut di atas diperoleh koefisien determinasi $\left(\mathrm{r}^{2}\right)=$ 0,341 . Hal ini berarti bahwa $34,1 \%$ variasi prestasi renang $100 \mathrm{~m}$ gaya bebas dapat dijelaskan oleh variasi komitmen. Hasil penghitungan koefisien korelasi sederhana $\mathrm{X}_{3}$ dengan $\mathrm{Y}\left(\mathrm{r}_{\mathrm{y} 3}\right)$, diperoleh $\mathrm{r}_{\mathrm{y} 3}$ sebesar 
0,579 Signifikansi koefisien korelasi $\mathrm{r}_{\mathrm{y} 3}$ melalui uji-t, hasilnya seperti pada tabel 3.

Tabel 3. Hasil Penghitungan Korelasi $X_{3}$ dengan $Y$

\begin{tabular}{ll}
\hline Korelasi & $\mathrm{X}_{1}$ dengan $\mathrm{Y}$ \\
\hline $\mathrm{n}$ & 35 \\
$\mathrm{R}$ & 0,579 \\
$\mathrm{r}^{2}$ & 0,335 \\
$\mathrm{t}_{\text {hitung }}$ & 2,156 \\
$\mathrm{t}_{\text {tabel }}$ & \\
0,05 & 2,46 \\
0,01 & 1,70 \\
\hline
\end{tabular}

Hasil yang menunjukkan bahwa $\mathrm{t}_{\text {hitung }}=2,156>\mathrm{t}_{\text {tabel }} 1,70$, maka hipotesis yang berbunyi terdapat hubungan antara motivasi berprestasi dan prestasi renang $100 \mathrm{~m}$ gaya bebas, diterima. Artinya, terdapat hubungan yang signifikan antara motivasi berprestasi dan prestasi renang $100 \mathrm{~m}$ gaya bebas. Dari koefisien $\mathrm{r}_{\mathrm{y} 3}$ di atas diperoleh koefisien determinasi $\left(\mathrm{r}^{2}\right)=$ 0,335 . Artinya, bahwa $33,5 \%$ variasi prestasi renang $100 \mathrm{~m}$ gaya bebas dapat dijelaskan oleh variasi motivasi berprestasi.

Hasil penghitungan koefisien regresi diperoleh $\mathrm{b}_{1}=0,001, \mathrm{~b}_{2}=0,001$, dan $\mathrm{b}_{3}=$ 0,001 dan nilai konstanta a sebesar 0,224, sehingga hubungan antara konsep diri $\left(\mathrm{X}_{1}\right)$, komitmen $\left(\mathrm{X}_{2}\right)$, dan motivasi berprestasi $\left(\mathrm{X}_{3}\right)$ dengan prestasi renang $100 \mathrm{~m}$ gaya bebas dinyatakan dengan persamaan garis regresi $\hat{Y}=0,224+0,001 X_{1}+0,001 \mathrm{X}_{2}+$ $0,001 X_{3}$. Pengujian signifikansi persamaan regresi ganda $\hat{Y}=0,224+0,001 X_{1}+0,001$ $\mathrm{X}_{2}+0,001 \mathrm{X}_{3}$, digunakan analisis varians (anava)-uji $\mathrm{F}$ dengan kriteria uji signifikansi, jika $F_{\text {hit }}>F_{\text {tab, maka persamaan re- }}$ gresi ganda tersebut dinyatakan signifikan. Pada Tabel 4 terlihat bahwa $F_{\text {hit }}=10,446>$
$\mathrm{F}_{\mathrm{tab}}=4,48$, maka persamaan regresi ganda tersebut dinyatakan signifikan. Setelah pengujian signifikansi dan linieritas persamaan regresi ganda, dilanjutkan dengan penghitungan koefisien korelasi ganda, diperoleh $\mathrm{r}_{\mathrm{y}, 123}=0,709$. Untuk lebih jelasnya hasil penghitungan dapat dilihat pada Tabel 4.

\begin{tabular}{ll} 
Tabel 4. Hasil Penghitungan Koefisien \\
Korelasi Ganda \\
\hline Korelasi & $\mathrm{R}_{, 123}$ \\
$\mathrm{n}$ & 35 \\
$\mathrm{R}$ & 0,709 \\
$\mathrm{R}^{2}$ & 0,503 \\
$\mathrm{~F}_{\text {hitung }}$ & 10,446 \\
$\mathrm{~F}_{\text {tabel }}$ & \\
0,05 & 2,90 \\
0,01 & 4,48 \\
\hline
\end{tabular}

Hasil yang menunjukkan bahwa $F_{\text {hitung }}=10,446>F_{\text {tabel }} 4,48$, maka hipotesis yang berbunyi terdapat hubungan yang signifikan antara hubungan konsep diri $\left(\mathrm{X}_{1}\right)$, komitmen $\left(\mathrm{X}_{2}\right)$, dan motivasi berprestasi $\left(\mathrm{X}_{3}\right)$ dengan prestasi renang $100 \mathrm{~m}$ gaya bebas, diterima. Artinya, terdapat hubungan yang signifikan antara hubungan konsep diri $\left(\mathrm{X}_{1}\right)$, komitmen $\left(\mathrm{X}_{2}\right)$, dan motivasi berprestasi $\left(\mathrm{X}_{3}\right)$ dengan prestasi renang $100 \mathrm{~m}$ gaya bebas. Dari koefisien korelasi ganda $r_{y}, 123$ tersebut diperoleh koefisien determinasi $\left(\mathrm{R}^{2}\right)=0,503$. Artinya, bahwa $50,3 \%$ variasi prestasi renang $100 \mathrm{~m}$ gaya bebas dapat dijelaskan oleh variasi konsep diri $\left(\mathrm{X}_{1}\right)$, komitmen $\left(\mathrm{X}_{2}\right)$, dan motivasi berprestasi $\left(\mathrm{X}_{3}\right)$ secara bersama.

\section{Pembahasan}

Berdasarkan hasil pengujian beberapa hipotesis ternyata ketiga variabel bebas (konsep diri, komitmen, dan motivasi berprestasi) memiliki hubungan yang signifi- 
kan dengan variabel terikat (prestasi renang $100 \mathrm{~m}$ gaya bebas).

Hasil penelitian menunjukkan bahwa terdapat hubungan yang signifikan antara konsep diri dan prestasi renang $100 \mathrm{~m}$ gaya bebas. Temuan ini sejalan dengan teori bahwa konsep diri merupakan gambaran yang dimiliki individu tentang dirinya yang meliputi karateristik fisik, sosial, psikologis, emosional, aspirasi, dan prestasi (Hurlock dalam Wangmuba, 2009:1). Konsep diri perenang akan terbentuk sesudah perenang memiliki citra diri yang positif, dan meningkatkan kemampuan dalam menghadapi berbagai permasalahan yang disertai dengan ketahanan mental dalam menghadapi segala kemungkinan. Setyobroto (2000:56) menjelaskan bahwa "Konsep diri setelah individu memiliki citra diri positif konstruktif, memiliki pandangan menyeluruh tentang dirinya (memahami kelebihan dan kekurangan), memiliki ketahanan dalam menghadapi berbagai kemungkinan (tantangan, hambatan, kegagalan), dan memiliki rencana hidup yang mantap".

Selanjutnya, hasil penelitian menunjukkan bahwa terdapat hubungan yang signifikan antara komitmen dan prestasi renang $100 \mathrm{~m}$ gaya bebas. Temuan ini sejalan dengan teori bahwa komitmen merupakan kekuatan yang mengikat seorang individu untuk melakukan aksi yang relevan dengan sasaran tertentu (Meyer \& Herscovitch, 2001:98). Selain itu, komitmen merupakan sesuatu yang membuat seseorang rela membulatkan hati dan tekad demi mencapai sebuah tujuan, sekalipun ia belum dapat mengetahui hasil akhir dari tujuan tersebut (Jenny, 2009:2). Perenang yang memiliki komitmen kuat akan berusaha sekuat tenaga, berjerih payah, dan berkorban demi menyelesaikan tujuannya, sekalipun semua orang meninggalkannya. Dengan demikian, komitmen merupakan langkah atau tindakan yang diambil perenang untuk menopang suatu pilihan tindakan tertentu, sehingga pilihan tindakan itu dapat dijalankan dengan mantap dan sepenuh hati. Oleh karena itu, perenang yang memiliki komitmen memiliki semangat yang luar biasa untuk melakukan tugas dan kewajibannya dan selalu termotivasi dan gigih dalam meraih target yang ingin dicapainya, sehingga prestasi puncak bisa dicapai dengan baik. Panggabean (2010:1) menjelaskan bahwa eksistensi komitmen pada diri atlet dapat dilihat dari beberapa indikator: (1) kecintaan pada perannya; (2) kepercayaan pada misi dan tujuan yang sedang dibebankan kepadanya; (3) keterikatan untuk menjaga nama baik perannya; (4) tanggapan terhadap tantangan yang ada; (5) dan keikhlasan dalam menjalankan tugasnya.

Selanjutnya, hasil penelitian menunjukkan bahwa terdapat hubungan yang signifikan antara motivasi berprestasi dan prestasi renang $100 \mathrm{~m}$ gaya bebas. Temuan ini sejalan dengan teori bahwa motivasi berprestasi merupakan keinginan seseorang untuk menyelesaikan suatu tugas yang sulit atau dorongan dalam mengatasi rintangan dan memelihara kualitas kerja yang tinggi, serta bersaing melalui usaha untuk melebihi perbuatan yang lampau atau mengungguli orang lain. Motivasi berprestasi merupakan dorongan yang ada pada diri seseorang yang berkaitan dengan prestasi, yang memiliki ciri-ciri menguasai, memanipulasi, mengatur lingkungan sosial maupun fisik, mengatasi rintangan-rintangan, dan memelihara kualitas kerja yang tinggi, bersaing melalui usaha-usaha untuk melebihi perbuatannya yang lampau serta mengungguli perbuatan orang lain. Pendapat lain terkait dengan motivasi berprestasi yaitu motivasi yang mendorong individu untuk mencapai sukses, dan bertujuan untuk 
berhasil dalam kompetisi, atau persaingan dengan beberapa ukuran keunggulan (standard of excelence). Ukuran keunggulan itu dapat berupa prestasi sendiri sebelumnya atau prestasi orang lain.

Selain itu, motivasi berprestasi disebut dengan istilah N.Ach (Need for Achievement). Apruebo (2005:53) menjelaskan: "Achievement motivation as a desire for significant accomplishment for mastery of things, people, or ideas for attaining a higher standard". Pendapat yang sama dijelaskan oleh Weinberg and Gould (2007) "Achievement motivation as a person's orientations to strive for task success, persist in the face of failure, and experience pride in accomplishments". Motivasi berprestasi memberikan kesempatan kepada atlet untuk mencapai sesuatu dengan sempurna, meningkatkan kebugaran pada tingkatan tertinggi, dan berlatih secara maksimal. Dengan kata lain motivasi berprestasi dalam olahraga sama dengan istilah "competitiveness". Apruebo (2005: 53) menjelaskan: "Competitiveness as a disposition to strive for satisfaction when making comparisons with some standard of excellence in the presence of evaluative other". Motivasi berprestasi pada hakikatnya merupakan keinginan, hasrat, kemauan, dan pendorong untuk dapat unggul yaitu mengungguli prestasi yang pernah dicapainya sendiri atau prestasi yang dicapai oleh orang lain. Motivasi berprestasi merupakan dorongan untuk berpacu dengan keunggulan, baik keunggulan dirinya sendiri, keunggulan orang lain, atau kesempurnaan dalam melaksanakan tugas tertentu. Berdasarkan beberapa kajian teori tersebut disimpulkan bahwa motivasi berprestasi adalah dorongan yang ada pada diri seseorang untuk mencapai sukses dan menghindari kegagalan, yang menimbulkan kecenderungan perilaku untuk mempertahankan dan meningkatkan suatu keberhasilan yang telah dicapai yang berpedoman pada patokan prestasi terbaik yang pernah dicapai baik oleh dirinya maupun orang lain. Perenang yang memiliki motivasi berprestasi akan cenderung memiliki kerja keras untuk mencapai apa yang diinginkannya, sehingga prestasi maksimal akan mudah untuk dicapainya.

Hasil temuan terakhir bahwa terdapat hubungan yang signifikan antara konsep diri, komitmen, dan motivasi berprestasi secara bersama-sama dengan prestasi renang $100 \mathrm{~m}$ gaya bebas. Temuan dalam penelitian ini sejalan dengan teori bahwa faktor psikologis memegang peranan penting dalam mencapai prestasi maksimal. Faktor psikologis (konsep diri, komitmen, dan motivasi berprestasi) memberikan dukungan terhadap prestasi perenang. Para ahli berpendapat bahwa prestasi tinggi akan dicapai manakala atlet memiliki kemampuan fisik, teknik, taktik, dan mental atau psikologis. Sebab betapa sempurnanya perkembangan fisik, teknik, dan taktik atlet, apabila mentalnya tidak turut berkembang, prestasi tinggi tidak mungkin akan dapat dicapai. Selain itu, berdasarkan telaah literatur bahwa latihan mental efektif untuk meningkatkan performa atlet.

Beberapa hasil penelitian, seperti Duran \& Salmela (2002: 154-171) menjelaskan: "That successful elite athletes and coaches use mental training techniques and strategies to help them achieve success in sport". Heishman \& Bunker (Komarudin, 2012: 5) menjelaskan: "Found that although $81 \%$ of elite athletes from various countries rated mental preparation as very important, only $44 \%$ made frequent use of mental preparation strategies and techniques." Selain itu, Davis \& Clugston (Komarudin, 2012:5) menjelaskan bahwa terkait dengan faktor mental dalam olahraga yang lain, misalnya bola basket, khususnya 
dalam tembakan bebas (free throw-shooting) menunjukkan bahwa latihan mental bermanfaat jika dikombinasikan dengan latihan fisik. Manfaat latihan mental dalam olahraga sudah terlihat jelas. Untuk itu, Sugarman (2008:1) menegaskan: "Sport is 90 to 95\% mental, athletes and coaches at all levels say it." Ungkapan para ahli tersebut memberikan penegasan bahwa aspek mental atau aspek psikologis memberikan pengaruh yang signifikan terhadap prestasi atlet, khususnya prestasi atlet renang $100 \mathrm{~m}$ gaya bebas.

\section{PENUTUP}

Berdasarkan analisis data yang telah dikemukakan pada bagian terdahulu, maka penelitian ini disimpulkan sebagai berikut. Pertama, terdapat hubungan yang signifikan antara konsep diri dan prestasi renang $100 \mathrm{~m}$ gaya bebas. Kedua, terdapat hubungan yang signifikan antara komitmen dan prestasi renang $100 \mathrm{~m}$ gaya bebas. Ketiga, terdapat hubungan yang signifikan antara motivasi berprestasi dan prestasi renang $100 \mathrm{~m}$ gaya bebas. Keempat, terdapat hubungan yang signifikan antara konsep diri, komitmen, dan motivasi berprestasi secara bersama-sama dengan prestasi renang $100 \mathrm{~m}$ gaya bebas.

Berdasarkan beberapa hasil temuan dalam penelitian ini, disampaikan beberapa rekomendasi sebagai berikut. Pertama, dalam proses pelatihan aspek psikologis terkait dengan konsep diri, komitmen, dan motivasi berprestasi hendaknya selalu ditanamkan kepada perenang, khususnya perenang gaya bebas. Kedua, disarankan kepada para pelatih dan pembina agar memperhatikan aspek psikologis dalam setiap proses pelatihan yang terintegrasi dalam sebuah periodesasi latihan. Ketiga, disarankan kepada peneliti untuk meneliti lebih lanjut terkait dengan variabel yang penulis teliti dengan menggunakan subjek yang lebih representatif baik pada subjek putra maupun putri, dengan tujuan agar menghasilkan data yang lebih akurat dan hasil penelitiannya dapat digeneralisasikan.

\section{UCAPAN TERIMA KASIH}

Pada kesempatan ini penulis mengucapkan terima kasih dan penghargaan yang tinggi kepada semua pihak, terutama Dr. Yunyun Yudiana, Dr. Bambang Abduljabar, Dr. Nina Sutresna, Dadan Mulyana, M.Pd., Dede Rohmat Nurjaya, M.Pd., Ira Purnamasari, M.Pd., dari Universitas Pendidikan Indonesia, dan semua pihak yang telah banyak memberikan kontribusi baik secara konseptual maupun teknis sehingga penelitian ini dapat diselesaikan dengan baik. Semoga amal baik yang telah Ibu/ Bapak berikan mendapat imbalan yang sepadan dari Tuhan Yang Maha Kuasa. Terakhir, penulis mengucapkan terima kasih kepada Pengelola Jurnal Cakrawala Pendidikan dari Universitas Negeri Yogyakarta yang telah berkenan mempublikasikan artikel ilmiah ini.

\section{DAFTAR PUSTAKA}

Apruebo, A.R. 2005. Sport Psychology. Manila: Publishing House.

Bradford, Strand and Royalne, Wilson. 1993. Assesing sport skills. Champaign. Il: Human Kinetics Publishers.

Cox, R.H. 2002. Sport Psychology: Concept and application psychology. Iowa:Wm.C. Brown Publishers.

Creswell, John W. 2010. Educational Research, Planning, Conducting, and Evaluating Quantitative and Qualitative Research. New Jersey: Pearson Merill Prentice Hall. 
Federation Internationale De Natation Amateur. 2010. Constitution and Rules. Switzerland: FINA Office.

Durand, Bush and Salmela. 2002. "The Development and Maintenance of Experts Athlete Performance: Perceptions of World and Olympic Champions". Journal of Applied Sport Psychology, 14, 154-171.

Husdarta. J.S. 2010. Psikologi Olahraga. Bandung: Alfabeta.

Jenny, J. 2009. Komitmen. Tersedia: http://www.jakartalantern.com (diunduh 23 Mei 2012).

Komarudin. 2012. Latihan Keterampilan Mental. Bandung: Rosda Karya.

Meyer dan Herscovitch. 2001. Commitment in the Workplace: Toward a General Model. London: Blackwell Scientific Publications.
Panggabean, Rizal. 2010. Komitmen dan De-komitmen. Tersedia: http://diahkei.staff.ugm.ac.id (diunduh 23 Mei 2012).

Setyobroto, Sudibyo. 1989. Psikologi Olahraga. Jakarta: Anam Kosong Anam.

Sugarman, Karlene. 2008. Why Mental Training. (Online): Tersedia: http//questia.com/psychology.

Wangmuba. 2009. Konsep diri. [Online]. Tersedia: http://wangmuba.com (Diunduh 23 Mei 2012).

Weinberg, R.S. \& Gould, D. 2007. Fondation of Sport and Exercise Psychology. $\left(4^{\text {th }}\right)$. Auckland: Human Kinetics. 